ISSN 1991- 8690

Website: http://jsci.utq.edu.iq

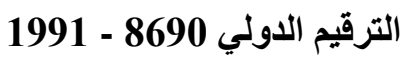

Email: utjsci@utq.edu.iq

\title{
The evaluation of some hematological parameters of human tuberculosis in Thi-Qar Province
}

\author{
Nafaa. F. M. Al-Farhan \\ Manal B. Al-Tamemi \\ Khalid G. Al -Fartosi
}

Thi-Qar University. College Of Science. Biology Department

E-mail: nafaam34 @ yahoo.com

Tel: 07800460770

\begin{abstract}
$\underline{\text { Abstract }}$
The present study aimed to evaluation of erythrocyte sedimentation rate (ESR), hemoglobin (Hb.) levels, white blood cell count (WBCs) in active and latent tuberculosis patients in Thi-Qar province,Iraq. This study included 210 samples (70 patients, 70 household contacts and 70 control ) with age's $\leq 10$ to $\geq 70$ years who were referred to ALNasiriya Center of Tuberculosis and Chest Diseases from the period September 2012 - July 2013.The study showed that the values erythrocyte sedimentation rate indicated a significant increase $(\mathrm{P} \leq 0.05)$ in patients and HHCs groups when compared with the value of control group $(42.64,22.93 \mathrm{vs} .8 .79 \mathrm{~mm} / \mathrm{h}$, respectively). While the results showed a significant decrease $(\mathrm{P} \leq 0.05)$ in the hemoglobin, $(\mathrm{Hb}$.) levels of patients group and HHCs when compared with control group (8.63 and $11.84 v s .13 .17 \mathrm{gm} / \mathrm{dl}$, respectively). The means of white blood cell (WBCs), showed a significant increase in patient and household when compared with correspondent value of control groups.
\end{abstract}

Keywords: Tuberculosis, ESR, Hb, WBC.

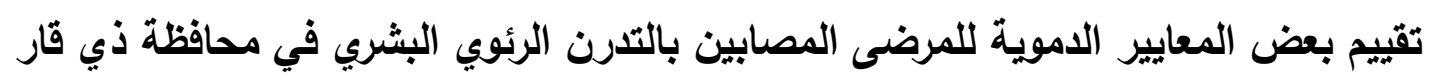

$\underline{\text { الخلاصة }}$

الدراسة الحالية هدفت الى تقييم معدل ترسيب كريات الدم الحمراء، مستوى خضاب الدم و العدد الكلي لكريات الدم البيض لمرضى التدرن الحاد والكامن

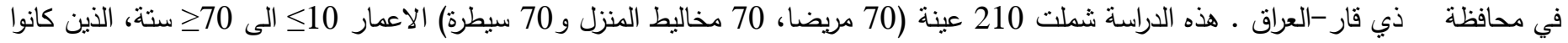
يراجعون الى مركز الناصرية للتدرن والامراض الصدرية للفترة من ايلول 2012 الى حزيران 2013. اوضحت الدراسة ان معدل ترسيب كريات الدم الحمراء

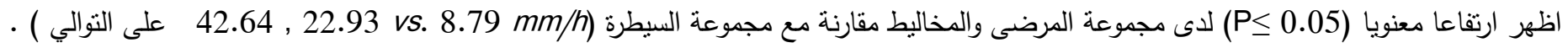

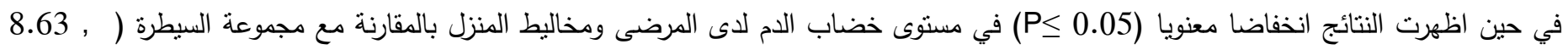
الت 11.84 vs. 13.17 gm/dl

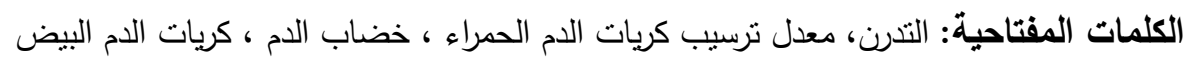

\section{Introduction:}

Tuberculosis (TB) is an infectious disease caused by the bacterium, namely Mycobacterium tuberculosis and responsible for taking away so many lives all over the world. According to World Health Organization (WHO), TB is considered the second only to HIV/AIDS as the greatest killer worldwide (WHO, 2012).Primary infections with Mycobacterium tuberculosis produce active disease in approximately 10
$\%$ of those infected (Ahmad, 2011). M. tuberculosis $T B$-antigen specific immunity usually successfully controls the pathogen, although viable bacteria do remain in granulomas for extend periods, this is known as latent tuberculosis infection (LTBI) (Huynh, 2011). Also, depend on many criteria a patient was considered as active pulmonary TB case if he has symptoms for 3 weeks or more with one of the following: fever, night sweating, loss of weight, persistent cough, tiredness, 
loss of appetite and fatigue. (Khatri, 2002; CDC, 2010). In 2011, 8.7 million people became infected and suffered from active TB and 1.4 million died due to this disease (WHO, 2012). WHO survey found that over 95 $\%$ of TB death occurs in low and middle incoming countries (WHO, 2012). Reactivation of latent tuberculosis (TB) may be induced by the administration of cytotoxic chemotherapy and high dose corticosteroid therapy (Adzic, 2004). In patients with pulmonary TB: anemia, leukocytosis and a high erythrocyte sedimentation rate (ESR) can occur ( Olaniyi and Aken'Ova, 2003).

\section{Material And Methods:}

This study was conducted in AL-Nasiriya Center of Tuberculosis and Chest Diseases, Thi-Qar province, Iraq from the period (September 2012-July 2013). The samples were obtained from 70 patients with active pulmonary tuberculosis, 70 household contacts (HHCs) and 70 controls. The patients and their HHCs were investigated for the presence of LTBI and active TB. The tests we used in this study are erythrocyte sedimentation rate (ESR), Hemoglobin levels (Hb.) and white blood cells count (WBCs). (CELL-DYN Ruby made all these investigations)

\section{Samples Collection:}

The patients and their HHCs ( $n=70$ of each) were interviewed using a structured questionnaire to collect information on socio demographic and clinical features and history of TB. In addition, they were clinically examined.

\section{Blood samples:}

Two ml of blood were collected by vein puncture and putted in test tube containing anticoagulant EDTA, ESR, $\mathrm{Hb}$. And Total WBCs count were examined according to (Lewis et al., 2001).

\section{Statistical Analysis}

Statistical analysis was made using SPSS, version 10.0. (5).(Newman, 2001).

\section{Results}

\section{Hematological study Erythrocyte Sedimentation Rate (ESR) values}

The results indicated a significant increase $(\mathrm{P}<0.05)$ in the erythrocyte sedimentation rate (ESR) of patients group $(42.64 \pm 10.27 \mathrm{~mm} / \mathrm{h})$ and household contact group (HHCs) $(22.93 \pm 6.86 \mathrm{~mm} / \mathrm{h})$ compared with control group $(8.79 \pm 2.74 \mathrm{~mm} / \mathrm{h})$. The highest mean of ESR was in the age group 31-40 year $(55.92 \pm 9.31 \mathrm{~mm} / \mathrm{h})$ of the patients group and lower mean was $(29.10 \pm 9.81 \mathrm{~mm} / \mathrm{h})$ in the age group $\leq 10$. The highest mean of ESR of the HHCs group was in the age groups 51-60 year $(38.28 \pm 10.46 \mathrm{~mm} / \mathrm{h})$, (Table 1).

Table (1): The rate of ESR in patients with TB, HHCs and control $(\mathrm{mm} / \mathrm{h})$

\begin{tabular}{|c|c|c|c|}
\hline \multirow{2}{*}{ Age group } & \multicolumn{3}{|c|}{ ESR rate $\mathrm{mm} / \mathrm{h}$} \\
\cline { 2 - 4 } & $\begin{array}{c}\text { Control } \\
\text { (Mean } \pm \text { St.D.) }\end{array}$ & $\begin{array}{c}\text { Patient } \\
(\text { Mean } \pm \text { St.D. })\end{array}$ & $\begin{array}{c}\text { Household contact } \\
\text { (Mean } \pm \text { St.D. })\end{array}$ \\
\hline$\leq 10$ & $4.05 \pm 1.03$ & $29.10 \pm 9.81$ & $4.89 \pm 1.33$ \\
\hline $11-20$ & $5.47 \pm 1.87$ & $38.80 \pm 10.32$ & $19.51 \pm 7.27$ \\
\hline $21-30$ & $7.62 \pm 2.04$ & $53.25 \pm 11.19$ & $15.79 \pm 4.79$ \\
\hline $31-40$ & $7.33 \pm 2.05$ & $55.92 \pm 9.31$ & $34.20 \pm 10.55$ \\
\hline $41-50$ & $10.21 \pm 3.30$ & $53.52 \pm 11.19$ & $22.75 \pm 6.25$ \\
\hline $51-60$ & $13.37 \pm 5.05$ & $38.80 \pm 10.32$ & $38.28 \pm 10.46$ \\
\hline$\geq 70$ & $13.52 \pm 3.89$ & $29.10 \pm 9.81$ & $25.15 \pm 7.41$ \\
\hline Mean & $8.79 \pm 2.74$ & $* 42.64 \pm 10.27$ & $* * 22.93 \pm 6.86$ \\
\hline
\end{tabular}

* significant difference $(\mathrm{p} \leq 0.05)$ of the patients and HHCs groups compared with controls.

**significant difference $(P \leq 0.05)$ of the HHCs compared with patients R.L.S.D.t $=4.48$

\section{Hemoglobin level (Hb)}

The results showed a significant decrease $(\mathrm{P}<0.05)$ in the $\mathrm{Hb}$ levels of patients group $(8.63 \pm 1.13 \mathrm{~g} / \mathrm{dl})$ and HHCs group $(11.84 \pm 1.67 \mathrm{~g} / \mathrm{dl})$ compared with control group $(13.17 \pm 1.33 \mathrm{~g} / \mathrm{dl})$. Also, there was a significant reduce $(\mathrm{P}<0.05)$ in $\mathrm{Hb}$ level of patients group compared with the HHCs group. The heights mean of $\mathrm{Hb}$ levels was in the age group 31-40 year $(9.68 \pm 2.11 \mathrm{~g} / \mathrm{dl})$ and lower mean was recorded by patients with age group $\geq 70$ year $(6.54 \pm 0.52 \mathrm{~g} / \mathrm{dl})$. While the heights mean was in the age group 31-40 year $(9.68 \pm 2.11 \mathrm{~g} / \mathrm{dl})$. In HHCs group, the lower mean of $\mathrm{Hb}$ levels was in the age group 11-20 year $(10.80 \pm 1.43 \mathrm{~g} / \mathrm{dl})$. Moreover, the heights mean was in the age group $\geq 70$ year $(12.21 \pm 1.91 \mathrm{~g} / \mathrm{dl})($ Table 2$)$. 
Table (2): The rate of $\mathrm{Hb}$ levels $(g / d l)$ in patients with TB, HHCs and control

\begin{tabular}{||c|c|c|c|}
\hline \multirow{2}{*}{ Age group } & \multicolumn{3}{|c|}{$\mathrm{Hb} g / d l$} \\
\cline { 2 - 4 } & $\begin{array}{c}\text { Control } \\
\text { (Mean } \pm \text { St.D.) }\end{array}$ & $\begin{array}{c}\text { Patient } \\
(\text { Mean } \pm \text { St.D. })\end{array}$ & $\begin{array}{c}\text { Household contact } \\
\text { (Mean } \pm \text { St.D. })\end{array}$ \\
\hline$\leq 10$ & $11.81 \pm 2.61$ & $6.54 \pm 0.52$ & $12.05 \pm 1.61$ \\
\hline $11-20$ & $12.75 \pm 1.35$ & $9.34 \pm 1.43$ & $10.80 \pm 1.43$ \\
\hline $21-30$ & $13.64 \pm 1.20$ & $9.48 \pm 0.97$ & $12.00 \pm 2.00$ \\
\hline $31-40$ & $13.40 \pm 0.74$ & $9.68 \pm 2.11$ & $11.97 \pm 1.55$ \\
\hline $41-50$ & $13.50 \pm 1.23$ & $9.48 \pm 0.97$ & $11.97 \pm 1.65$ \\
\hline $51-60$ & $13.63 \pm 0.74$ & $9.34 \pm 1.43$ & $11.91 \pm 1.60$ \\
\hline$\geq 70$ & $13.49 \pm 1.50$ & $6.54 \pm 0.52$ & $12.21 \pm 1.91$ \\
\hline Mean & $13.17 \pm 1.33$ & $* 8.63 \pm 1.13$ & $* * 11.84 \pm 1.67$ \\
\hline
\end{tabular}

*significant difference $(\mathrm{p} \leq 0.05)$ of the HHCs and patient groups compared with controls

**significant difference $(P \leq 0.05)$ of the $\mathrm{HHCS}$ compared with patients, R.L.S.D.t $=0.43$

\section{White blood cell count (WBCs)}

The results showed a significant increase $(\mathrm{P}<0.05)$ in the White blood cell count (WBCs) of patients group $\left(15.40 \pm 1.48 \mathrm{cell} / \mathrm{mm}^{3}\right)$ and household contacts group $\left(9.86 \pm 2.56 \mathrm{cell} / \mathrm{mm}^{3}\right)$ compared with control group $\left(7.78 \pm 1.87 \mathrm{cell} / \mathrm{mm}^{3}\right)$. Also, there was a significant increase $(\mathrm{P}<0.05)$ in WBCs of patients group compared with household contacts group. There was no a significant among age groups of the patients and HHCs (Table 3).

Table (3): The rate of WBCs in patients with TB, HHCs and control $(\mathrm{mm} / \mathrm{h})$

\begin{tabular}{|c|c|c|c|}
\hline \multirow{2}{*}{$\begin{array}{l}\text { Age } \\
\text { group }\end{array}$} & \multicolumn{3}{|c|}{$\mathrm{WBC}$ s rate $\mathrm{cell} / \mathrm{mm}^{3}$} \\
\hline & $\begin{array}{c}\text { Control } \\
(\text { Mean } \pm \text { St.D. })\end{array}$ & $\begin{array}{c}\text { Patient } \\
(\text { Mean } \pm \text { St.D. })\end{array}$ & $\begin{array}{l}\text { Household contact } \\
(\text { Mean } \pm \text { St.D. })\end{array}$ \\
\hline$\leq 10$ & $8.86 \pm 1.66$ & $16.83 \pm 1.19$ & $7.49 \pm 2.65$ \\
\hline $11-20$ & $6.93 \pm 1.64$ & $13.78 \pm 1.42$ & $11.53 \pm 3.15$ \\
\hline $21-30$ & $7.25 \pm 2.04$ & $14.88 \pm 1.71$ & $9.86 \pm 2.00$ \\
\hline $31-40$ & $6.58 \pm 1.19$ & $16.33 \pm 1.77$ & $10.63 \pm 3.27$ \\
\hline $41-50$ & $8.99 \pm 2.88$ & $15.29 \pm 1.40$ & $9.39 \pm 2.04$ \\
\hline $51-60$ & $8.37 \pm 2.66$ & $15.33 \pm 1.44$ & $10.50 \pm 3.11$ \\
\hline$\geq 70$ & $7.47 \pm 1.02$ & $15.36 \pm 1.48$ & $9.60 \pm 1.71$ \\
\hline Mean & $7.78 \pm 1.87$ & $* 15.40 \pm 1.48$ & $* * \quad 9.86 \pm 2.56$ \\
\hline
\end{tabular}

*significant difference $(\mathrm{p} \leq 0.05)$ of the patients and HHCs groups compared with controls.

**significant difference $(P \leq 0.05)$ of the HHCs compared with patients, R.L.S.D.t $=1.04$

\section{Discussion}

The rate of erythrocyte sedimentation rate (ESR) was a significant increase in the patients group and household contacts group (HHCs). This result probably due to the presence of extended families in AL-Nasiriya district associated with crowding, poverty, malnutrition and presence of grandfathers or grandmothers who may be harboring active pulmonary TB (Bashour and Mamaree, 2003). In addition, there was a significant increase of the ESR rates in the age group 31-40 year of the patients 51-60 year of the HHCs group compared with other groups. The increase in the ESR of this age groups may be attributed to exposure these persons to dust for prolonged periods resulting from industrial pollutants, chemicals and fumes resulting from car exhaust and thus frequent exposure to these pollutants increases the problems of respiratory system. This is consistent with study of Holst et al. (2010) who mentioned thatentry large amounts of dust to the respiratory stream loaded with bacterial and fungal spores increase the infections of respiratory system. This result in agreement with study of Unsalet al. (2005) who referred to rise ESR to $61.1 \mathrm{~mm} / \mathrm{h}$. The high a significant decrease of the hemoglobin level in the patients and household can be explained in the ground that most the antibiotics that used for treatment of TB caused anorexia that lead to malnutrition, or due to malnutrition, which caused by poverty and in ability to follow the correct dietary habits because they have symptoms similar to $\mathrm{TB}$ infection that causes the anorexia which leads to malnutrition, also bad nutrition habits, low education level are reasons which have clear impact to reduce $\mathrm{Hb}$. This result is consistent with study of Crevelet al. (2002) which reported the decrease in hemoglobin level totals age groups in patients with tuberculosis attributed to treatment with antibiotics life for long periods. Low level of the Hemoglobin in the age group $\geq 70$ year of the patients and age group 11 20year of the HHCs may be attributed to wronguse of antibiotics or anemia disease, their dependence onfoodhas no nutritional value and old age could be interpreted as a risk factor for TB-associated anemia and malnutritionof the infected children this consistent with study by Choi et al. (2004) which who mentioned that the prevalence of anemia usually increases with age especially after age 60 year. There was a significant increase in the white blood cell count among study groups. This result may be due to the role of the immune system in the resistance against infection with pulmonary tuberculosis. this increase refers to a 
significant difference indicate the role of WBCs as an important component of the host defense system, responsible for protection against bacteria.This increase in the pre-treatment stage is high and this in agreement with finding of Teklu and AL-wabel, (1994). Also our result match with the study by AL-Mamory, (2012) in Iraq, which demonstrated that, there is a significant increase in the WBCs count of the TB patients compared with control group. Also, match with finding of study done by AL-Nahary, (2002) in Iraq who observed that rise in the mean of WBCs in patients with tuberculosis.

\section{References}

AL-Mamory, A. A. . (2012). Isolation and identification some Bacteria and fungal

associated with tuberculosis patients with study of some immunological and inflammatory in Babylon Province. A thesis of $\mathrm{M}$. Sc.University of Babylon.

Al-Nahari,A.M.(2002). Immunological and Cytogenetic Evaluation in patients with

Tuberculosis.A thesis ofPh.D.University of Baghdad.

Adzic,T. (2004). Pulmonary tuberculosis in patients with hematological malignanciies.Med Pregl.57:65-68.

Ahmad, S. (2011). Pathogenesis, immunology, and diagnosis of latent Mycobacterium tuberculosis infection. J.Clinical and Developmental Immunology, Article ID 814943:17.

Bashour, h. and F., Mamaree. (2003). Gender differences and tuberculosis in Syria

Arab Republic: patientssttitudes, compliance and outcomes Eastern Mediterranean

health journal.9:757-768.

CDC and Prevention. Tuberculosis. ( 2010 a). Department of Health and Human Services- Centers for Disease Control and Prevention.

Choi, CW.; J., Lee ; KH ., Park ; SY., Yoon ; IK ., Choi ; SC., Oh ; JH ., Seo ;BS., Kim ; SW., Shin ;YH., Kim ; JS., Kim. (2004). Prevalence and characteristics of anemia in the elderly: crosssectional study of three urban Korean population samples. Am J. Hematol, 77: 26-30 .

Crevel,R.; H.,Tom and W., Jos. (2002). Innate immunity to Mycobacteriuntubercullosis.Clin.Micro. Review., 15(2): 294- 309.
Folkehelseinstituttet. (2002). For ebygging og kontroll av tuberkulose: en veileder(Guidelines for prevention and control of tuberculosis) 7th edition. Oslo, Folkehe lseinstituttet; 122.

Holst, B.; Hanas, S.; Berndtsson, L. and Hansson, L. (2010). Infections causes for feline upper respiratory tract disease a case control study. J. Med. Surg., 12 (10): 783 - 792.

Huynh, K.K ; Joshi, S.A. and Brown, E.J. (2011). A delicate dance: Host response to mycobacteria J. Curr. Opin. Immunol., 23: 464-472.

Khatri, G.R. and Frieden, T.R. ( 2002). Controlling tuberculosis in India. England Journal of medicine, 347:1420-1425.

Lewis, S. M.; B.J., Bain and I. Bates. (2001). Dacie and Lewis.Practical Hematology 9th ed Churchils livingstone, London

Newman,S.C..(2001). Bio statistical Methods in Epidemiology. 7th Ed. John Wily \&Sons, Inc. New York. 72-77.

Olaniyi, JA.; YA.,Aken'Ova.( 2003). Hematological profile of patients with pulmon- ary tuberculosis in Ibadan, Nigeria. Afr J. Med Med Sci.

Teklu, B. and A. AL-Wabael .(1994). Resolution of fever in patients on Chemotherapy Forpulmonary tuberculosis. J. Ann.Saudi Med., 392-395.

Unsal,E.;Aksaray,S.; Koksal and Sipit ,T.(2005). Potential role of interleukin- 6 in reactive thrombocytosis and acute phase response in pulmonary tuberculosis. J. Med

Micrbi., 81 : 604-607.

World Health Organization. (2012)."Tuberculosis", October, fact sheet $\mathrm{N}^{\circ} 104$. 